\title{
EFFECT OF USING DIFFERENT LEVELS OF MORINGA OLEIFERA MEAL IN THE DIETS OF JAPANESE QUAILS ON THEIR PRODUCTIVE PERFORMANCE
}

\author{
Walaa H. Khalifa, Ghada E. Abusinaa, G.M. Elmallah, S.A. Yassein, A.A., Elghamry and \\ Nagwa A. Maghraby \\ Animal Production Dept., National Research Centre, 33 El Bohouth St., Dokki, Giza, Egypt.
}

(Received 5/6/2018, accepted 16/7 /2018)

SUMMARY

$\mathrm{T}$ he aim of this study was to inspect the effect of feeding Japanese quail chicks on diets containing different levels of Moringa Oleifera meal (MOM) on productive performance, carcass quality and blood constituents. Six hundred unsexed one- week-old birds of Japanese quail were equally divided into five experimental groups of 120 birds each. They were fed at $0,5,10,15$ and $20 \%$ with MOM. The experiment lasted for six weeks during which the effect of MOM on the body weight, feed consumption, feed conversion, blood constituents and carcass traits were observed as indicator of performance. The results showed that, birds fed on $5 \%$ MOM gained significantly higher body weight and body weight gain than birds fed the control diet, but the lowest feed consumption $(\mathrm{P} \leq 0.01)$ and best feed conversion ratio were obtained by using 20\% MOM compared to control group. Using 20\% MOM increased the weight of heart and liver significantly $(\mathrm{P} \leq 0.05)$ than other groups, but there were no significantly $(\mathrm{P}>0.05)$ differences in gizzard, carcass and edible parts weights of the growing Japanese quails in the four treatments. Plasma total protein and albumin were significantly higher in two groups (15 and $20 \%) \mathrm{MOM}$ as compared to other treated groups or control group. The best level of MOM was $20 \%$ which recorded a decrease in plasma cholesterol and LDL compared to control group, but plasma AST and ALT decreased with all levels of MOM. This study indicate that the $20 \%$ MOM diet can improve quail performance without negative effects on growth and carcass traits.

Keywords: Quails, Moringa oleifera meal, growth performance, carcass.

\section{INTRODUCTION}

Poultry production is one of the fastest ways to ameliorate deficiency of animal protein supply and consumption in many countries. This is because of high rate of reproduction, their short generation interval, and efficiency of nutrient conversion into high quality protein. Quail farming is used to diversify the poultry industry and help in domestic chicken production. This is because of great benefits derived from quails. Quail belongs to the family Phasianidae, genus Coturnix bonnaterre and species Coturnix coturnix japonica. Commercial quail farming is becoming more popular and is being increasingly promoted in number of Asian and European countries (E.F.S.A 2004 and RSPCA, 2011) and recently in Africa. Quail is reared for its excellent meat including its nutritive and economic benefits (Odugbo, 2004). Quail meat and egg are renowned for their high-quality protein, high biological value and low caloric content (Agiang, 2011) they are highly nutritional, containing essential minerals and vitamins. Despite their small size, the nutritional value of quail eggs is three to four times greater than chicken eggs (Tunsaringkarn et al., 2013). Igado and Aina (2010) reported that quail meat is tastier than chicken and promotes body and brain development in children. Quail meat is a sweet and delicate white game meat with extremely low skin fat and low cholesterol value. The prices of soybean and fish meals which are widely and successfully used as conventional protein sources for poultry production have been escalating continuously in recent times, whilst their availability is often erratic. The problem has been worsened due to the increasing competition between humans and animals for these protein ingredients as food. According to (Odunsi, 2003) the rapid growth of human and livestock population, which is creating increased needs for food and feed in the less developed countries, demands that alternative feed 


\section{Khalifa et al.}

resources must be identified and evaluated. One possible source of cheap protein is the leaf meals of some tropical legume browse plants, i.e. Moringa oleifera as an important feed resources which are relatively rich in crude protein (25-44\%), essential amino acids, minerals, carotenoids and vitamins (Houndonougbo et al., 2012). Amongst those resources, Moringa oleifera is an excellent feedstuff due to its adaptability to varieties of climatic conditions, high leaf yield and a great deal of active substances of health care (Ly et al., 2001). Thus, the aim of this study is to verify the ability of Moringa oleifera meal and its effect on productive performance of Japanese quails .

\section{MATERIALS AND METHODS}

A total number of 600 unsexed one- week-old Japanese quail chicks were randomly and equally divided into five experimental groups of 120 birds each, ( 3 replicates of 40 birds each). All chicks were housed in battery brooders equipped with raised wire floors and were reared under similar environmental, managerial and veterinarian conditions. Lighting programs was provided about 23 hours daily. Feed and water were offered ad-libitum during the experimental period which lasted for six weeks.

The experimental diets were prepared by mixing MOM into the five experimental diets at the rate of control (T1) without MOM, while the other four diets were supplemented with 5, 10, 15 and 20\% MOM (T2,T3,T4 and T5 , respectively) . All diets were kept to be iso-nitrogenous (24\% crude protein) and isocaloric (2900 ME/kg of diet) to supply birds requirements according to NRC (1994). The ingredients and chemical composition of the experimental diets are presented in Table 1. Body weight and feed consumption (FC) were recorded at the end of the $1^{\text {st }}, 3^{\text {rd }}$ and $6^{\text {th }}$ weeks of age. Body weight gain (BWG) and feed conversion were then calculated.

Table (1): Composition and calculated analysis of the experimental diets.

\begin{tabular}{lccccc}
\hline Ingredient \% & Control & 5\% MOM & 10\% MOM & 15\% MOM & 20\% MOM \\
\hline Yellow corn & 57.1 & 57.8 & 58.3 & 59.1 & 59.8 \\
Soybean meal (44\%) & 34.0 & 29.5 & 25.3 & 20.0 & 15.0 \\
Corn glutiene meal (62\%) & 6.0 & 4.8 & 3.5 & 3.0 & 2.3 \\
Moringa olifera meal & 0 & 5.0 & 10.0 & 15.0 & 20.0 \\
Di-calcium phosphate & 0.8 & 0.8 & 0.8 & 0.8 & 0.8 \\
Limestone & 1.35 & 1.35 & 1.35 & 1.35 & 1.35 \\
Sodium chloride & 0.4 & 0.4 & 0.4 & 0.4 & 0.4 \\
Vit. Min. Pre mix.* & 0.3 & 0.3 & 0.3 & 0.3 & 0.3 \\
Dl-methionine & 0.05 & 0.05 & 0.05 & 0.05 & 0.05 \\
Total & 100 & 100 & 100 & 100 & 100 \\
Calculated analysis ** & & & & & 23.98 \\
Crude protein \% & 23.99 & 23.93 & 23.92 & 23.95 & 2881 \\
ME Kcal/kg & 2892 & 2886 & 2876 & 1.24 & 1.19 \\
Lysine \% & 1.24 & 1.24 & 1.24 & 0.44 & 0.43 \\
Methionine \% & 0.45 & 0.45 & 0.45 & 0.37 & 0.34 \\
Cystine \% & 0.37 & 0.37 & 0.37 & 0.96 & 0.89 \\
Calcium \% & 0.96 & 0.96 & 0.96 & 0.46 & 0.45 \\
Available-P \% & 0.46 & 0.46 & 0.46 & \\
\hline
\end{tabular}

* Vitamins and minerals premix were free from folic acid: each $\mathrm{kg}$ contains vit A $12000 \mathrm{Iu}$, vit.D3 $3000 \mathrm{Iu}$, vit. E 12 $\mathrm{mg}$, vit. $\mathrm{K} \mathrm{lmg}$, vit B12 $0.02 \mathrm{mg}$, vit B1 $1 \mathrm{mg}$, vit B2 $4 \mathrm{mg}$, vit B6 $5 \mathrm{mg}$, Nicotinic acid $20 \mathrm{mg}$, Biotin $0.05 \mathrm{mg}$, Choline chloride $0.16 \mathrm{mg}$, cupper $3 \mathrm{mg}$, iron $30 \mathrm{mg}$, manganese $40 \mathrm{mg}$, zinc $45 \mathrm{mg}$ and selenium $3 \mathrm{mg}$.

** According to N.R.C. (1994)

At the end of the experimental period, slaughtering was performed on a random sample of five birds from each treatment to estimate some carcass characteristics. Also, blood samples were collected in heparinized tubes, and centrifuged at 3000rpm for 15 minutes to separate clear plasma which stored at $20^{\circ} \mathrm{C}$ for determination of some blood constituents as total protein (Gornal et al., 1949), albumin (Doumas and Waston 1971), transaminases activity (AST, aspartate amino-transferase, ALT alanine amino-transferases (Reitman and Frankle, 1957) while LDL; triglycerides and total lipids and cholesterol (Zollner and Kirsch, 
1962) were determined by spectrophotometer using available commercial kits. Data were statistically analyzed using the general linear model for analysis of variance of SAS (SAS, 2001). Test of significance for the differences between means was done by Duncan's multiple range test (Duncan, 1955).

\section{RESULTS AND DISCUSSION}

\section{Productive performance:}

Productive performance as affected by dietary treatments is explained in Table 2. The results indicated that live body weight and body weight gain at three and six weeks of age were significantly $(\mathrm{P}<0.01)$ higher in $\mathrm{T} 2(5 \% \mathrm{MOM})$ than the control group and others received diet with $15,20 \%$ of (MOM). This study confirms previous findings by Kakengi et al. (2007) that indicated Moringa Leaf Meal promoted good growth and productivity in poultry is attributed to its nutrients and phytochemicals. Also, Fuglier (1999) and Ebenebe et al. (2012) reported high performance of livestocks fed on moringa based diet. This finding might be due to natural enzymes in moringa which facilitate digestion of fibrous food in animals and improve bioavailability of nutrients (Foidl et al., 2001). From Table 2, it was observed that quail birds feeding diet with $20 \%$ of moringa had the lowest feed intake (109, 404 and $514.5 \mathrm{~g})$ during the experiment. Feed conversion ratio $(\mathrm{FCR})$ was significantly $(\mathrm{P}<0.05)$ affected by adding moringa to the diets. FCR decreased in group 3 that received diet with $20 \%$ MOM than other groups during this experiment. Feed conversion ratio decreased with increasing level of MOL in the diet. This can be explained by the decrease in feed intake associated with increasing level of MOL in the diet. This result agrees with the conclusion of Ayssiwede et al. (2012) and Houndonougbo et al. (2012). This result is nearly similar to those of Ashong and Brown (2011) who reported that the control group had higher feed intake compared to other groups of chickens fed Moringa oleifera leaf meals. Also, Portugaliza and Fernandez (2012) observed that adding Moringa oleifera aqueous leaf extracts in drinking water significantly decreased feed intake of broilers as the concentration increased. This could be as a result of improved digestion and metabolism activities of Moringa oleifera (Gakuya et al., 2012)

Table (2): Effect of different levels of Moringa oleifera on productive performance of the growing quail.

\begin{tabular}{|c|c|c|c|c|c|}
\hline \multirow[b]{2}{*}{ Treatments } & $\mathrm{T} 1$ & $\mathrm{~T} 2$ & T3 & $\mathrm{T} 4$ & T5 \\
\hline & Control & $5 \%$ & $10 \%$ & $15 \%$ & $20 \%$ \\
\hline \multicolumn{6}{|l|}{ Body weight } \\
\hline $1^{\text {st }}$ week & $23.06+0.15$ & $23.16+0.12$ & $23.12+0.15$ & $23.17+0.13$ & $23.12+0.13$ \\
\hline $3^{\text {rd }}$ week & $72.62^{\mathrm{b}} \pm 0.61$ & $97.41^{\mathrm{a}} \pm 4.29$ & $76.61^{\mathrm{b}}+1.19$ & $76.04^{\mathrm{b}} \pm 1.04$ & $75.73^{\mathrm{b}} \pm 0.37$ \\
\hline $6^{\text {th }}$ week & $177.37^{\bar{b}} \pm 1.68$ & $195.01^{\mathrm{a}} \pm 0.18$ & $194.09^{\mathrm{a}} \pm 1.64$ & $177.50^{\bar{b}} \pm 1.42$ & $164.40^{\mathrm{c}} \pm 2.81$ \\
\hline \multicolumn{6}{|l|}{ Weight gain } \\
\hline From1-3week & $74.34^{\mathrm{a}}+4.17$ & $49.47^{\mathrm{b}}+0.70$ & $53.49^{\mathrm{b}}+1.09$ & $52.87^{\mathrm{b}}+1.18$ & $52.60^{b}+0.44$ \\
\hline from4-6 week & $79.96^{\mathrm{d}} \pm 3.71$ & $122.38^{\mathrm{a}} \pm 0.44$ & $117.47^{\mathrm{a}} \pm 1.46$ & $101.46^{\overline{\mathrm{b}}} \pm 1.00$ & $88.68^{\bar{c}} \pm 2.49$ \\
\hline from $1-6$ week & $154.30^{\bar{b}}+1.72$ & $171.85^{a}+0.29$ & $170.96^{a}+1.49$ & $154.32^{\mathrm{b}}+1.53$ & $141.28^{\bar{c}}+2.92$ \\
\hline \multicolumn{6}{|l|}{ Feed intake } \\
\hline from 1-3 week & $188.80^{\mathrm{a}} \pm 8.33$ & $111.96^{b}+2.63$ & $114.69^{b}+5.22$ & $110.40^{\mathrm{b}}+1.97$ & $109.16^{\mathrm{b}}+1.98$ \\
\hline from4 -6 week & $427.49^{\mathrm{c}} \pm 37.80$ & $578.44^{\mathrm{a}} \pm 9.16$ & $599.29^{\mathrm{a}} \pm 8.05$ & $495.59^{b} \pm 12.29$ & $404.14^{\mathrm{c}} \pm 14.33$ \\
\hline from 1-6 week & $616.29^{\mathrm{b}} \pm 29.87$ & $690.40^{\mathrm{a} \pm 1} \pm 11.25$ & $713.98^{\mathrm{a}} \pm 12.87$ & $604.75^{\mathrm{b}} \pm 10.32$ & $514.53^{\mathrm{c}} \pm 16.27$ \\
\hline \multicolumn{6}{|l|}{ Feed conversion } \\
\hline from 1-3 week & $2.54^{\mathrm{a}} \pm 0.03$ & $2.26^{\mathrm{b}} \pm 0.02$ & $2.14^{\mathrm{c}} \pm 0.06$ & $2.10^{\mathrm{c}} \pm 0.02$ & $2.07^{\mathrm{c}} \pm 0.03$ \\
\hline from $4-6$ week & $5.32^{\bar{a}}+0.23$ & $4.73^{\mathrm{bc}}+0.09$ & $5.10^{\mathrm{ab}}+0.07$ & $4.88^{\mathrm{bc}}+0.09$ & $4.55^{\bar{c}}+0.05$ \\
\hline from 1-6 week & $3.99^{\mathrm{a}} \pm 0.20$ & $4.02^{\mathrm{a}} \pm 0.06$ & $4.18^{\mathrm{a}} \pm 0.05$ & $3.94^{\mathrm{ab}} \pm 0.08$ & $3.64^{\mathrm{b}} \pm 0.05$ \\
\hline
\end{tabular}

$a, b . c d$ Means in the same row with different superscripts are significantly different $(p<0.01)$. 


\section{Khalifa et al.}

\section{Carcass Characteristics:}

The results for carcass parts weights of the growing quails fed different levels of Moringa oleifera leaf meal as a partial replacement for soybeans meal are shown in (Table 3).

Table (3): Effect of different levels of Moringa oleifera on carcass weights of the growing quails.

\begin{tabular}{lccccc}
\hline & $\mathrm{T} 1$ & $\mathrm{~T} 2$ & $\mathrm{~T}$ & $\mathrm{~T}$ & $\mathrm{~T}$ \\
\cline { 2 - 6 } Treatments & Control & $5 \%$ & $10 \%$ & $15 \%$ & $20 \%$ \\
\hline Head w. & $3.50^{\mathrm{b}} \pm 0.19$ & $4.16^{\mathrm{ab}} \pm 0.18$ & $3.65^{\mathrm{b}} \pm 0.29$ & $4.73^{\mathrm{a}} \pm 0.21$ & $3.79^{\mathrm{b}} \pm 0.24$ \\
Heart w. & $0.82^{\mathrm{ab}} \pm 0.04$ & $0.71^{\mathrm{ab}} \pm 0.13$ & $0.61^{\mathrm{b}} \pm 0.11$ & $0.80^{\mathrm{ab}} \pm 0.12$ & $0.98^{\mathrm{a} \pm 0.09}$ \\
Liver w. & $2.50^{\mathrm{ab}} \pm 0.41$ & $1.54^{\mathrm{b} \pm 0.11}$ & $1.83^{\mathrm{ab}} \pm 0.15$ & $2.15^{\mathrm{ab}} \pm 0.22$ & $2.74^{\mathrm{a}} \pm 0.54$ \\
Gizzard & $1.81 \pm 0.13$ & $2.37 \pm 0.18$ & $2.25 \pm 0.10$ & $2.37 \pm 0.03$ & $2.08 \pm 0.02$ \\
Carcass & $73.08 \pm 0.82$ & $72.36 \pm 0.76$ & $69.58 \pm 1.32$ & $70.25 \pm 2.47$ & $69.55 \pm 1.41$ \\
edible w. & $78.46 \pm 1.26$ & $76.97 \pm 0.90$ & $74.28 \pm 1.35$ & $75.58 \pm 2.74$ & $75.13 \pm 2.74$ \\
\hline$a, b . c$ Means in the same row with different superscripts are significantly different $(p<0.01)$ &
\end{tabular}

Weight of the heart and liver in T5 (0.98 and 2.74 gram) were significantly $(\mathrm{P} \leq 0.05)$ higher than other groups, where the mean gizzard, carcass and edible weights of the growing Japanese quails in the four treatments were not significantly $(\mathrm{P}>0.05)$ different from one to another. However, the significant difference observed in the weight of the heart and liver between T5 and other treatments are contrary to the non-significant difference reported by Safa and Tazi (2012) in broiler chicken. The non-significant difference found in mean gizzard ,carcass and edible weights of the growing Japanese quails in all treatments are similar to the finding of Zanu et al. (2012) and Safa and Tazi (2012) who confirmed that, none of the parameters measured for carcass characteristics in birds fed with diets containing Moringa oleifera leaf meal was significantly affected by inclusion of Moringa leaf meal. Also, they found that the dietary herbal supplement of $0.1 \%$ of moringa increased the gizzard fat content.

\section{Blood constituents:}

The results of the blood plasma parameters at 6 weeks as affected by dietary Moringa oleifera are shown in Table (4).

Table (4): Effect of different levels of Moringa oleifera on blood constituents of the growing quails.

\begin{tabular}{lccccc}
\hline & \multicolumn{1}{c}{ T1 } & $\mathrm{T} 2$ & $\mathrm{~T} 3$ & $\mathrm{~T} 4$ & $\mathrm{~T}$ \\
\cline { 2 - 6 } Treatments & Control & $5 \%$ & $10 \%$ & $15 \%$ & $20 \%$ \\
\hline Total protein (g/dl) & $6.64^{\mathrm{b}} \pm 0.19$ & $7.05^{\mathrm{ab}} \pm 0.18$ & $6.76^{\mathrm{b}} \pm 0.20$ & $7.57^{\mathrm{a}} \pm 0.19$ & $7.38^{\mathrm{a}} \pm 0.17$ \\
Albumin (g/dl) & $3.93^{\mathrm{bc}} \pm 1.41$ & $3.84^{\mathrm{bc}} \pm 1.33$ & $3.66^{\mathrm{c}} \pm 1.22$ & $4.14^{\mathrm{ab}} \pm 1.12$ & $4.35^{\mathrm{a}} \pm 1.32$ \\
Globulin (g/dl) & $2.71^{\mathrm{b}} \pm 0.18$ & $3.21^{\mathrm{b}} \pm 0.18$ & $3.10^{\mathrm{b}} \pm 0.28$ & $3.43^{\mathrm{a}} \pm 0.20$ & $3.03^{\mathrm{b}} \pm 0.23$ \\
A/G ratio & 1.45 & 1.20 & 1.18 & 1.21 & 1.44 \\
Triglyceride (mg/dl) & $148.45^{\mathrm{a}} \pm 0.19$ & $142.86^{\mathrm{b}} \pm 0.15$ & $137.89^{\mathrm{c}} \pm 0.11$ & $134.78^{\mathrm{c}} \pm 0.17$ & $127.95^{\mathrm{d}} \pm 0.21$ \\
Cholesterol (mg/dl) & $186.95^{\mathrm{a}} \pm 0.90$ & $173.20^{\mathrm{b}} \pm 0.84$ & $166.50^{\mathrm{c}} \pm 0.77$ & $171.00^{\mathrm{b}} \pm 0.92$ & $164.30^{\mathrm{c}} \pm 0.65$ \\
LDL (mg/dl) & $65.54 \pm 1.19$ & $62.75 \pm 1.14$ & $60.81^{ \pm} \pm 1.17$ & $60.57 \pm 1.23$ & $59.12 \pm 1.27$ \\
Creatinie (mg/dl) & $0.94^{\mathrm{a}} \pm 0.76$ & $0.87^{\mathrm{b}} \pm 0.54$ & $0.85^{\mathrm{b}} \pm 1.46$ & $0.83^{\mathrm{b}} \pm 1.97$ & $0.82^{\mathrm{b}} \pm 1.09$ \\
ALT ( U/L) & $66.33^{\mathrm{a}} \pm 0.18$ & $59.83^{\mathrm{ab}} \pm 0.23$ & $56.67^{\mathrm{b}} \pm 0.36$ & $54.33^{\mathrm{b}} \pm 0.29$ & $50.00^{\mathrm{b}} \pm 0.34$ \\
AST (U/L) & $92.90^{\mathrm{a}} \pm 2.74$ & $86.40^{\mathrm{ab}} \pm 1.73$ & $77.00^{\mathrm{b}} \pm 2.31$ & $76.20^{\mathrm{b}} \pm 1.10$ & $71.40^{\mathrm{b}} \pm 0.79$ \\
\hline
\end{tabular}

$a, b$ Means in the same row with different superscripts are significantly different $(p<0.01)$.

Results showed that total protein and albumin were significantly increased in the fourth (T4) group (7.57 and 4.14) and fifth (T5) group (7.38 and 4.35) as compared to other treated groups. Total plasma protein has been reported as an indication of the protein retained in the animal body (Akinola and Abiola, 1991). The relatively greater total plasma protein content of broilers receiving dietary MOM might be an indication of the good protein content and/or quality of the leaf meal. The dietary inclusion of MOM 
effect on plasma levels of albumin led to significant improvements in plasma globulin compared than control. While, $\mathrm{A} / \mathrm{G}$ ratio reduction in all moringa treatments and this means that immunity of birds fed different MOM additives were improved compared to the control group. This result is also supported by the works of Olugbemi et al. (2010) who reported that Moringa oleifera leaves had a beneficial effect on the immune responses and improve intestinal health of broilers .Though Moringa oleifera has been claimed to boost immune systems (Fuglier, 1999), such property of the plant most likely might be contained and restricted to the pods which possesses lectin, a substance that modulates the body defense system (Jayavardhanan et al., 1994). On contrary, Makanjuola et al. (2014) found that $0.2 \%, 0.4 \%$ and 0.6 MOLM did not influence the serum total protein, albumin, globulin and AST. But ALT significantly decreased in the birds fed on diet $(0.4 \%)$. Thus, the efficient nutrient utilization noted in this study in MOLM supplemented birds may suggest tissue bio-efficiency of polyphenols or their metabolites present in M. oleifera leaves (Brenes et al., 2008). However, plasma cholesterol, LDL and triglycerides had significantly increased in control group $(1.48,186.95$ and 65.54) compared to all MOM treatments (Table 4). The best level of MOM was $20 \%$ which recorded decrease in plasma cholesterol and LDL compared to control group. Similar results have been obtained by Dey and De (2013) who found that 0.25 or $0.40 \%$ MOLM in broiler diets was significant $(\mathrm{P}<0.01)$ reduced in total cholesterol, triglycerides and LDL-cholesterol. Plasma AST and ALT decreased with all levels of MOM. Since liver is reported to contain enzymes like ALT and AST, it releases these enzymes to the blood when damaged (Kaplan et al. ,2003). Hence, the significant differences among treatment and control diets in plasma AST in the present study may reflect normal liver function of the birds fed diets containing moringa. Although the decrease in ALT activity observed in birds on diet contained 20\% of MOL could suggest that MOLM has properties that can enhance liver health. Similar results have been obtained by Dey and De (2013) who found that 0.25 or $0.40 \%$ MOLM in broiler diets was significant .

\section{CONCLUSION}

This study indicated that the $20 \%$ moringa leaf diet can improve Quail performance without negative effect on blood parameters.

\section{REFERENCES}

Agiang, E.A., O.O.K. Oko and G.E. Essien (2011). Quails response to aqueous extract of bush Marigold (Aspiliaafricana) Leaf. American Journal of Animal and Veterinary Sciences,6 (4):130-134.

Akinola, A.O. and S.S.Abiola, (1991).Blood chemistry and carcass yield of cockerels fed melon husk diets. Trop. J. Anim. Sci., 2: 39-44.

Ashong JO and D.L. Brown (2011).Safety and efficacy of Moringa oleifera powder for growing poultry. Journal of Animal Science, 89:84

Ayssiwede SB , C. Chrysostome , W. Ossebi , A. Dieng , J.L. Hornick (2012). Effets de l'incorporation de la farine de feuilles de Cassia tora (Linn.) dans la ration alimentaire de jeunespouletstraditionnels du Sénégal.Revue de MédecineVétérinaire 163: 375-386.

Brenes, A. , A .Viveros , I. Gon , C. Centeno , S.G. Sa' yago-Ayerdy, I. Arija, and F. Saura-Calixto (2008) . Effect of grape pomace concentrate and vitamin E on digestibility of polyphenols and antioxidant activity in chickens. Poult. Sci.,87 :307-316.

Dey, A. and P.S. De (2013).Infiuence of Moringa oleifera leaves as a functional feed additive on the growth performance, carcass characteristics and serum lipid profile of broiler chicken. indian Journal of Animal Research; 47 Issue 5, p449.

Duncan , D.B. (1955). Multiple range and multiple F. test. Biometrics, 11: 1-42

Doumas, B.T. and W. Waston (1971) . Albumin standards and measurement of plasma albumin with bromocresol green. Clin. Chem. Acta., 31: 87. 


\section{Khalifa et al.}

Ebenebe, C.L. , A. Co. Umegechi and BO. Nweze (2012).Comparison of haematological parameters and weight changes of broiler chicks fed different levels of Moringa oleifera diet. Inter. J. Agric. Bio Sci. $1: 23-25$.

EFSA (2004). Opinion of the Scientific Panel on Plant health, Plant protection products and their Residues on a request from the Commission related to the evaluation of methamidophos in ecotoxicology in the context of Council Directive 91/414/EEC. The EFSA Journal 144: 1-50.

Foidl, N., H.P.S. Makkar and K. Becker ( 2001 ).The potential of Moringa oleifera for agricultural and industrial uses. What development potential for Moringa products? Oct 20th - November 2nd 2001, darEs Salaam. 20 pp.

Fuglier, L . J. (1999)The miracle tree:Moringa oleifera.Natural nutrition for the tropics Church World Service,Dakkar, Senegal, pp 68.

Gakuya, D.W. , P.N. Mbugua , B . Kavoi and S.G. Kiama Effect of supplementation of Moringa oleifera leaf meal in broiler chicken feed. International Journal of Poultry Science 2012:13:201-213.

Gornal , A.G. , C.J. Bardawill and M.M. Divid (1949).Determination of plasma protein by means of the biurent reaction. J. Biol. Chem., 177: 751

Houndonougbo M.F., C.A.A.M. Chrysostome, V.P. Houndonougbo (2012). Performances de ponte et qualité des œufs des poulespondeuses ISA Brown alimentées avec des rations à base de feuillesséchées de manioc (Manihotesculenta, Crantz). International Journal of Biological Chemical Science 6: 1950-1959.

Igado, O. O. and O. O. Aina (2010). Some Aspects of the Neurometrics and Oculometrics of the Japanese Quail (Coturnixcoturnix japonica) in Nigeria. Journal of Morphological. Science, 27(3-4): 133-135.

Jayavardhanan, K.K. , K . Suresh , K . R . Panikkar and D.M. Vasudevan (1994). Modular potency of drumstick lectin on the host defense system. J. Exp. Clin. Cancer Res., 13: 205-209.

Kakengi, A. , J. Kaijage, S. Sarwatt, S. Mutayoba, M. Shem and T. Fujihara(2007).Effect of Moringa oleifera leaf meal as a substitute for sunflower seed meal on performance of laying hens in Tanzania. Livest.Res.Rural Dev., 19.

Kaplan, L.A., A. J. Pesce , and S.C. Kazmierczak (2003).Liver Function. In: Sherwin, J.E. (Ed.), Clinical Chemistry, fourth edition. Elsevier Science, St. Louis, Toronto 1179p.

Ly J, P. Samkol and T.R. Preston (2001) Nutritional evaluation of tropical leaves of pigs: pepsin/pancreatin digestibility of thirteen plant species. Livestock Research for Rural Development 13: 5 .

Makanjuola ,B.A. ,O.O.Obi, , T.O., Olorungbohunmi, O.A. Morakinyo , M. O. Oladele-Bukola, and B.A. Boladuro (2014). Effect of Moringa oleifera leaf meal as a substitute for antibiotics on the performance and blood parameter Livestock Research for Rural Development. Volume 26, Article

NRC (1994). National Research Council Nutrient requirements of poultry . ( $9^{\text {th }}$ edn) National Academy Press, Washington DC, USA.

Odugbo, M.O. (2004). Pasteurellosis in Japanese quail (Coturnix coturnix japonica) caused by Pasteurella multocida A:4. Vet. Record, 155: 90-91.

Odunsi , A.A. (2003 ). Assessment of Lablab purpureus leaf meal as a feed ingredient and yolk coloring agent on the diet of layers Int. J. Poultry Sci.,2 71- 74

Olugbemi ,T.S., S.K. Mutayoba, F.P. Lekule (2010). Evaluation of Moringa Oleifera leaf meal inclusion in cassava chip based diets fed to laying birds. Livestock Research for Rural Development; 22(6).

Portugaliza , H.P. and T. J. Fernandez (2012) Growth performance of Cobb broilers given varying concentrations of malunggay (Moringa Oleifera) aqueous leaf extract. Journal of Animal and Feed Research;2(6):465-469.

Reitman, S. and S. Frankel (1957).Determination of GOT and GPT Amr. J. Clin. Path., 28:56-63. 
(RSPCA, 2011). Royal Society for the Prevention of Cruelty to Animals Quail: Good practice for housing and care. Research Animals Department $.4^{\text {th }}$ edition.West Sussex RHI3 9RS. 2011.

Safa MA and El Tazi (2012). Effect of Feeding Different Levels of Moringa Oleifera leaf meal on the performance and carcass quality of broiler chicks. International Journal of Science and Research ,3(5):2319-7064.

SAS. SAS /STAT User's Guide (Release 8.2). SAS Inst. Inc., Cary NC, USA, 2001

Tunsaringkarn, T., W.Tungjaroenchai and W. Siriwong, (2013). Nutrient benefits of Quail (Coturnix coturnix japonica) eggs. International Journal of Scientific and Research Publications, 3(5):1-8.

Zanu H .K. , P. Asiedu , M. Tampuori , M. Abada and I. Asante (2012). Possibilities of using moringa (Moringa oleifera) leaf meal as a partial substitution for fish meal in broiler chicken diets. Journal of Animal and Feed Research;2(1)70-75.

Zollner, N. and K. Kirsch (1962). Determination of total lipids in blood by colorimetric method. Z. Ges. Exp. Med., 135: 454- 454.

تأثير استخدام مستويات مختلفة من المورينجا اوليفيرا في الوجبات الغذائية على الاداء الإتتاجي لطيور السمان اليابانية



تهاف هذه الدراسة لمعرفه تأثير تغذية طيور السمان اليابانية على الأنظمة الغذائية التي تحتوي على مستويات مختلفة من المورينجا

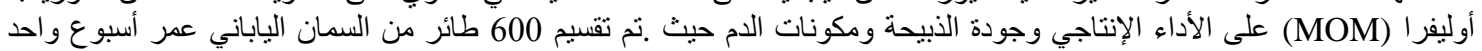

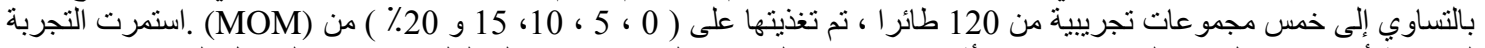

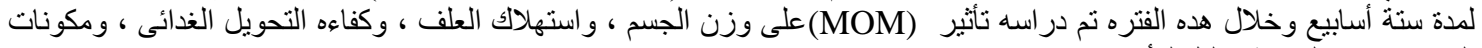
الدم وصفات الذبيحة كدليل للادداء.

أظهرت النتائج أن الطيور التي غذيت بنسبة 5) (MOM) اكتسبت زيادة كبيرة في وزن الجسم مقارنة بالطيور الني غذيت

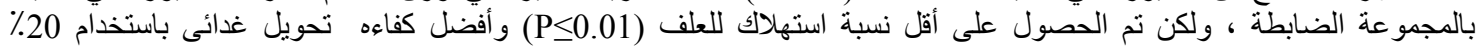

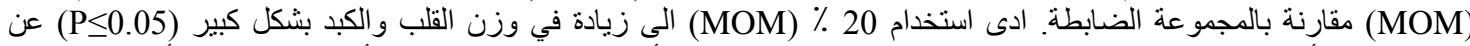

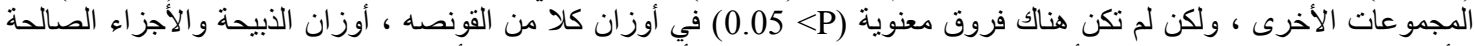

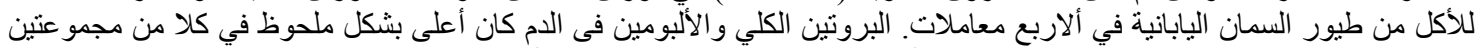

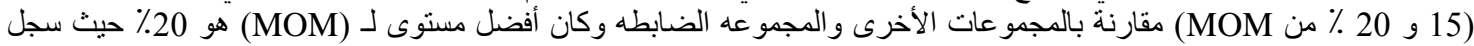

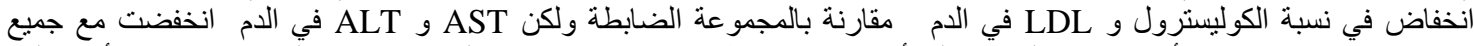

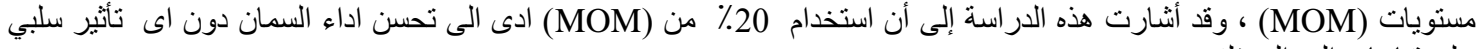

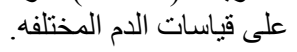

